\title{
Physiological and biochemical responses of diatoms to projected ocean changes
}

\author{
Juntian $\mathrm{Xu}^{1,2}$, Kunshan Gao ${ }^{1, *}$, Yahe $\mathrm{Li}^{1}{ }^{1}$, David A. Hutchins ${ }^{3}$ \\ ${ }^{1}$ State Key Laboratory of Marine Environmental Science, Xiamen University (Xiang-An campus, ZhouLongQuan A1-211), \\ Xiamen, Fujian 361102, PR China \\ ${ }^{2}$ School of Marine Science and Technology, Huaihai Institute of Technology, Lianyungang, Jiangsu 222005, PR China \\ ${ }^{3}$ Marine and Environmental Biology, Department of Biological Sciences, University of Southern California, \\ 3616 Trousdale Parkway, Los Angeles, California 90089, USA
}

\begin{abstract}
With progressive future global change, marine phytoplankton in surface oceans will be subjected to ocean acidification, as well as to increased solar exposures and decreased vertical transport of nutrients from depth due to increasing stratification. We employed a simultaneous multivariate treatment approach to investigate the physiological and biochemical responses of the diatoms Thalassiosira pseudonana and Skeletonema costatum to these projected ocean changes. Diatoms were grown under different 'clustered' regimes of solar radiation, nutrients, and $\mathrm{pCO}_{2}$ $(\mathrm{pH})$, reflecting present-day (2011) and potential mid-century (2050) and end-of-century (2100) scenarios. Growth rates, chlorophyll a contents and maximal photochemical quantum yield all decreased from the present to 2100 scenarios. While cellular particulate organic carbon significantly increased in both species along with increased cellular organic C:N ratios, biogenic silica content showed species-specific differences among the cluster treatments. Our results suggest that reduced thickness of the upper mixed layer with enhanced stratification may interact with ocean acidification to influence diatom-related biogeochemical processes by affecting their growth and biochemical composition in species-specific ways.
\end{abstract}

KEY WORDS: Biogenic silica · Growth · Multiple ocean changes · Particulate organic carbon Skeletonema costatum $\cdot$ Thalassiosira pseudonana

Resale or republication not permitted without written consent of the publisher

\section{INTRODUCTION}

Changes in the magnitude of primary production and associated biogeochemical cycles in the ocean have largely controlled geochemical processes of the Earth over 3 billion years (Falkowski et al. 1998). Marine primary producers respond to ocean acidification $\left(\mathrm{OA}_{\text {; }}\right.$ including reduced $\mathrm{pH}$ and altered carbonate chemistry associated with increasing atmospheric $\mathrm{CO}_{2}$ rise) and/or warming differentially according to their ecological niche, species diversity and other concurrent environmental forcing (Hutchins et al. 2009, 2013, Boyd et al. 2010, Riebesell \& Tortell 2011, Gao et al. 2012a, Fu et al. 2014). Interac- tions of changing levels of temperature (Fu et al. 2007), visible light (Feng et al. 2008, Gao et al. 2012b), UV radiation (Gao et al. 2009) or nutrients (Shi et al. 2010, W. Li et al. 2012) with OA can result in dramatically different effects on phytoplankton species compared to the impacts of $\mathrm{pH}\left(\mathrm{pCO}_{2}\right)$ alone.

Consequently, single or dual variable experimental designs have been suggested to be insufficient to take into account the confounding effects of mutual interactions between multiple environmental change variables (Boyd et al. 2010, Boyd 2011). To investigate the complex integrative effects of multiple ocean change factors, a new approach has been suggested for experimental designs that empirically tests 
the combined effects of simultaneously changed variables (Boyd et al. 2010). This approach, referred to as a 'cluster experiment', uses grouped variables to simulate the net effects of multiple concurrent changing factors. One experiment has been published using this new approach that tested the effects of cluster combinations of $\mathrm{CO}_{2}$, light, temperature and iron on the growth and physiology of Southern Ocean diatoms and prymnesiophytes (Xu et al. 2014).

Previously, OA effects on particular diatom species have been shown to vary with irradiance, including stimulatory effects under low or moderate levels of light (Wu et al. 2010, Gao et al. 2012b), or no effect (Tortell et al. 2000, Yang \& Gao 2012), or inhibitory effects under high light levels (Gao et al. 2012b, Li \& Campbell 2013). Regardless of these discrepancies, mitochondrial respiration and photorespiration were found to increase under OA conditions in the diatoms Phaeodactylum tricornutum and Thalassiosira pseudonana (Gao et al. 2012b) and a green alga Ulva prolifera (Xu \& Gao 2012). On the other hand, OA treatment has been shown to sometimes reduce mitochondrial respiration as well (Hennon et al. 2014). Usually, high-light grown algae respire faster (Verity 1982); therefore, the combination of increased exposure to both light and $\mathrm{CO}_{2}$ may lead to enhanced respiration.

Shipboard experiments showed that diatom abundance decreased at $\mathrm{CO}_{2}$ levels below 800-1000 $\mu \mathrm{atm}$ in the South China Sea (Gao et al. 2012b); however, diatom-dominated phytoplankton assemblages showed increased growth rates under similar levels of $\mathrm{CO}_{2}$ enrichment in the Ross Sea (Tortell et al. 2008). Obviously, diatom responses to OA may depend on species-specific metabolic pathways, as well as on the regional environmental conditions that they are adapted to (reviewed in Gao \& Campbell 2014).

Studies have also examined the combined effects of OA with light in diatom cultures (Wu et al. 2010) and field populations (Feng et al. 2010). OA interactions have additionally been determined for several groups of phytoplankton with temperature (Fu et al. 2007, Feng et al. 2008, 2009) and with UV radiation in the model diatom P. tricornutum (Y. Li et al. 2012), while several studies have examined interactions of warming with OA using natural marine diatom communities (Hare et al. 2007, Feng et al. 2009, Tatters et al. 2013).

Other than these studies, relatively little has been documented on the cumulative effects of multiple climate change factors on diatoms, despite their relevance to global nutrient and carbon cycles. Here, we examined the physiological and biochemical re- sponses of 2 cosmopolitan diatoms, T. pseudonana and Skeletonema costatum, under 3 progressive clustered environmental scenarios of $\mathrm{CO}_{2}$, light and nutrients that reflect projected surface ocean changes up to the end of this century.

\section{MATERIALS AND METHODS}

\section{Materials}

Experiments used the diatoms Thalassiosira pseudonana (CCMP 1335, originally isolated from Moriches Bay, Forge River, Long Island, NY, USA) and Skeletonema costatum (CCMA110, isolated from the South China Sea in 2004, from the Center for Collections of Marine Bacteria and Phytoplankton of the State Key Laboratory of Marine Environmental Science). Medium was prepared using natural offshore seawater from the South China Sea $\left(18^{\circ} \mathrm{N}, 111^{\circ} \mathrm{E}\right)$, sterilized and enriched with Aquil trace metals and vitamins (Sunda et al. 2005). The nutrient levels were designed to mimic future sequentially reduced supplies of nutrients due to enhanced stratification, as described below (see next subsection). Prior to being placed in the cluster treatments, the cells were grown exponentially in the media with the designated levels of nutrients and $\mathrm{CO}_{2}$ levels for at least 20 generations under indoor controlled conditions (photon flux density: $70 \mu \mathrm{mol} \mathrm{m} \mathrm{m}^{-2} \mathrm{~s}^{-1}$; temperature: $20^{\circ} \mathrm{C}$; $14 \mathrm{~h}$ light:10 h dark cycle).

\section{Experimental setup}

The cluster experiments were designed to mimic progressive OA and shoaling of the upper mixed layer (UML) caused by ocean warming and were carried out from July 26 to August 10, 2011. Three clusters were set up as follows: (1) a 2011 scenario (present day): ambient $\mathrm{CO}_{2}$ level (390 $\left.\mu \mathrm{atm}\right), 10 \%$ of the incident surface light, and nutrient concentrations of $20 \mu \mathrm{M} \mathrm{NO}_{3}{ }^{-}, 2 \mu \mathrm{M} \mathrm{PO}_{4}{ }^{3-}$ and $20 \mu \mathrm{M}$ silicate; (2) a 2050 scenario (mid-century): $700 \mu \mathrm{atm} \mathrm{CO}_{2}, 18 \%$ of surface light, and $10 \mu \mathrm{M} \mathrm{NO}{ }^{-}, 1 \mu \mathrm{M} \mathrm{PO}{ }_{4}{ }^{3-}$ and $10 \mu \mathrm{M}$ silicate; and (3) a 2100 scenario (end-century); $1000 \mu \mathrm{atm} \mathrm{CO}_{2}, 30 \%$ of incident light, with $5 \mu \mathrm{M}$ $\mathrm{NO}_{3}{ }^{-}, 0.5 \mu \mathrm{M} \mathrm{PO}_{4}{ }^{3-}$ and $5 \mu \mathrm{M}$ silicate (Table 1).

For the cluster treatments, the $\mathrm{CO}_{2}$ levels were based on the Intergovernmental Panel on Climate Change (IPCC) A1Fl scenario $\left(\mathrm{CO}_{2}\right.$ emission with 'business as usual' scenario). Present-day light levels were based on the median level of light and light 
Table 1. Light, $\mathrm{CO}_{2}, \mathrm{pH}$ and nutrient combinations used in the cluster experiment design

\begin{tabular}{|lcrrrrr|}
\hline $\begin{array}{l}\text { Sce- } \\
\text { nario }\end{array}$ & $\begin{array}{c}\text { Light }(\% \text { of } \\
\text { surface) }\end{array}$ & $\begin{array}{c}\mathrm{CO}_{2} \\
(\mu \mathrm{atm})\end{array}$ & $\mathrm{pH}$ & $\begin{array}{c}\mathrm{NO}_{3}{ }^{-} \\
(\mu \mathrm{M})\end{array}$ & $\begin{array}{c}\mathrm{PO}_{4}{ }^{3-} \\
(\mu \mathrm{M})\end{array}$ & $\begin{array}{c}\text { Silicate } \\
(\mu \mathrm{M})\end{array}$ \\
\hline 2011 & 10 & 390 & 8.18 & 20 & 2 & 20 \\
2050 & 18 & 700 & 7.96 & 10 & 1 & 10 \\
2100 & 30 & 1000 & 7.82 & 5 & 0.5 & 5 \\
\hline
\end{tabular}

attenuation coefficient within the UML of the South China Sea obtained during research cruises (Tseng et al. 2005). The levels of nutrients were set up according to the present-day levels of nutrients in the UML in the oligotrophic South China Sea (unpubl. data of '973' project No. 2009CB421207). Future changes are necessarily more speculative, as there are no models stating precisely what expected levels of light and nutrients will be in 2050 or 2100 . However, we assumed that year 2100 mean values for these 2 variables will resemble minimum (nutrients) or maximum (light) levels observed in the presentday South China Sea, according to the sources given above, and that year 2050 mean values will lie midway between present-day and year 2100 values. Polycarbonate bottles $(500 \mathrm{ml})$ were used in the experiment, and all the materials in contact with the cultures were glass-free to avoid Si contamination.
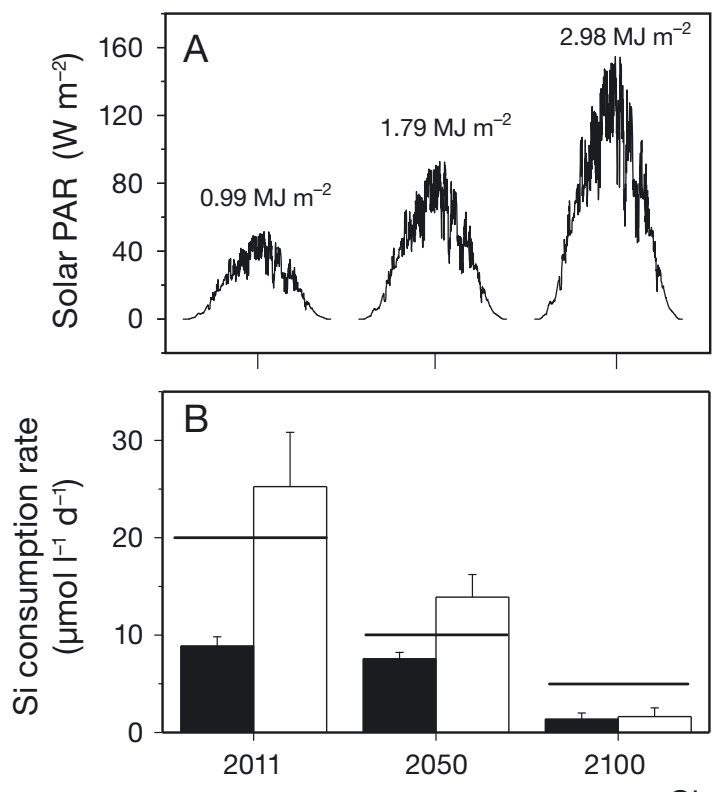

Cluster treatments
Each cluster treatment had 3 biological replicates; for some analyses, measurements for each of these triplicates were made and averaged on the last $3 \mathrm{~d}$ of the incubations $(\mathrm{n}=9)$.

Different levels of solar photosynthetically active radiation (PAR) were achieved with neutral density screens (4 layers for Cluster 1; 3 layers for Cluster 2; and 2 layers for Cluster 3 ), so that the cells received 10,18 and $30 \%$ of incident light in the respective cluster treatments. Solar PAR was measured with a broadband solar radiometer (ELDONET, Real Time Computer), which records the means over 1 min intervals. Irradiance levels were measured daily during the growth period, and values given represent the average of all days. The temperature was controlled at $21 \pm 1^{\circ} \mathrm{C}$ in all treatments using a cooling unit (CAP3000, Rikakikai). Due to logistical limitations, future temperature changes were not considered.

Average solar PAR doses during the growth experiment and levels of nutrients and $\mathrm{pH}$ are shown in Fig. 1. Average daytime solar PAR doses during the growth experiment were $0.99,1.79$ and $2.98 \mathrm{MJ} \mathrm{m}^{-2}$ for the 2011, 2050 and 2100 scenarios, respectively (Fig. 1A). Nutrient and $\mathrm{pH}$ levels were significantly different between the clusters (Fig. 1B-D) due to the semi-continuous dilutions that maintained cell concentrations within defined ranges (see next subsection).
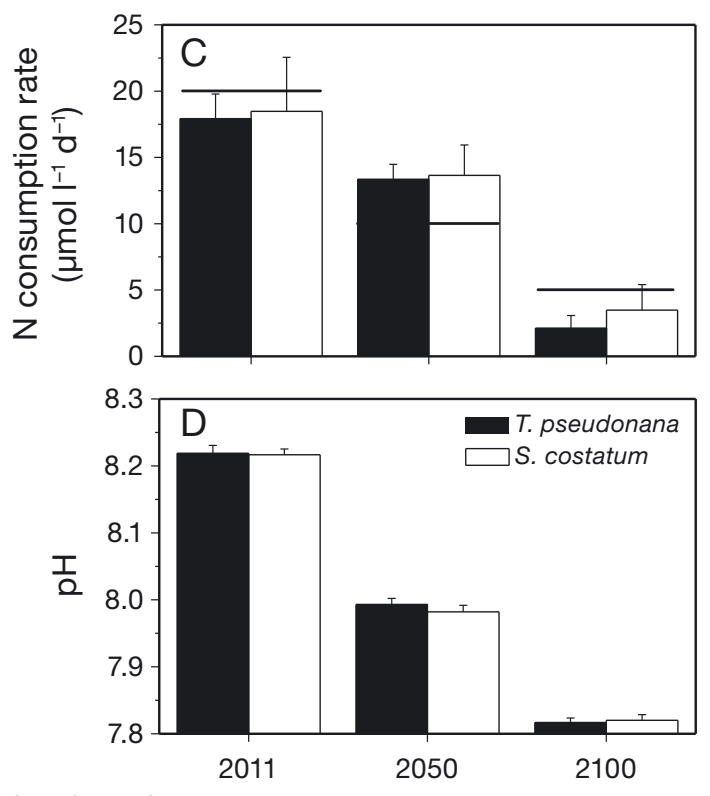

Fig. 1. (A) Daily solar photosynthetically active radiation (PAR), (B) Si consumption rate, (C) N consumption rate, and (D) pH, in cultures of Thalassiosira pseudonana and Skeletonema costatum under 3 cluster scenarios. Si and N consumption rates were estimated with the increase in cell concentration every $24 \mathrm{~h}$ and the elemental contents per cell. Horizontal lines in (B,C) represent the initial nutrient supply levels for every cluster. Error bars represent $\mathrm{SD}(\mathrm{n}=9)$ 
Target $\mathrm{pH}\left(\mathrm{pCO}_{2}\right)$ values in the cluster experiments were attained by bubbling $\left(300 \mathrm{ml} \mathrm{min}^{-1}\right)$ with ambient air, or using air with elevated $\mathrm{CO}_{2}$ concentrations (see Table 1) supplied from a portable $\mathrm{CO}_{2}$ enriching device $\left(\mathrm{CO}_{2}\right.$ enrichlor $\mathrm{CE}-100$, Ruihua) that automatically controls the $\mathrm{CO}_{2}$ concentration with a variation of less than $5 \%$. The initial cell densities in the semicontinuous cultures were $1 \times 10^{5} \mathrm{ml}^{-1}$, and cultures were diluted back to this same cell concentration after each $24 \mathrm{~h}$ of growth, so dilution levels were adjusted to the growth rate of each replicate bottle. Nutrient levels were also replenished at the same time by adding concentrated nutrient stocks (Fu et al. 2007, 2014, Sun et al. 2011). Because cell densities were maintained at low levels (always $<3 \times 10^{5} \mathrm{ml}^{-1}$ before diluting back to $1 \times 10^{5} \mathrm{ml}^{-1}$ ), the $\mathrm{pH}$ of the culture medium varied less than 0.05 units for all of the treatments in both diatom species (Fig. 1D).

Cell counting was carried out every $24 \mathrm{~h}$ for the last $3 \mathrm{~d}$ with a particle counter and size analyzer ( $\mathrm{Z} 2$ Coulter, Beckman) for T. pseudonana and with a hemocytometer for $S$. costatum before and after the medium dilutions. The specific growth rate $\left(\mu, d^{-1}\right)$ was calculated as: $\mu=\left(\ln C_{1}-\ln C_{0}\right) /\left(t_{1}-t_{0}\right)$, where $C_{0}$ and $C_{1}$ represent the cell concentrations at $t_{0}$ (initial or just after the dilution) and $t_{1}$ (just before the dilution), respectively.

After the cells were grown for $14 \mathrm{~d}$, the maximum efficiency of photosystem II, $F_{\mathrm{v}} / F_{\mathrm{m}}=\left(F_{\mathrm{m}}-F_{0}\right) / F_{\mathrm{m}}$ (where $F_{\mathrm{v}}$ is variable fluorescence, $F_{\mathrm{m}}$ is maximum fluorescence and $F_{0}$ is minimum fluorescence), was measured at noontime after 10 min dark adaption with a xenon-pulse amplitude modulated fluorometer (XE-PAM, Walz). Measurements of cellular particulate organic carbon (POC) and nitrogen (PON) were carried out by collecting the cells at the end of the growth experiment onto pre-combusted $\left(450^{\circ} \mathrm{C}\right.$, $6 \mathrm{~h}) \mathrm{GF} / \mathrm{F}$ filters (Whatman), acidifying the filters with fumes of $0.1 \mathrm{~N} \mathrm{HCl}$ for $12 \mathrm{~h}$ and drying in an oven at $60^{\circ} \mathrm{C}$ overnight, and then finally analyzing $\mathrm{C}$ and $\mathrm{N}$ contents with a CHNS/O analyzer (2400 Series II, PerkinElmer).

$\mathrm{Chl}$ a content and cellular biogenic silica (BSi) were measured at the end of the growth experiment. Chl a content was determined with a fluorometer (Trilogy, Turner Designs) following Welschmeyer (1994), and BSi was determined by collecting the cells on polycarbonate filters, followed by drying and analysis according to the spectrophotometric method of Brzezinski \& Nelson (1995).

Statistical analysis was performed with 1-way ANOVA (Tukey), and the significance level was set as $\mathrm{p}<0.05$.
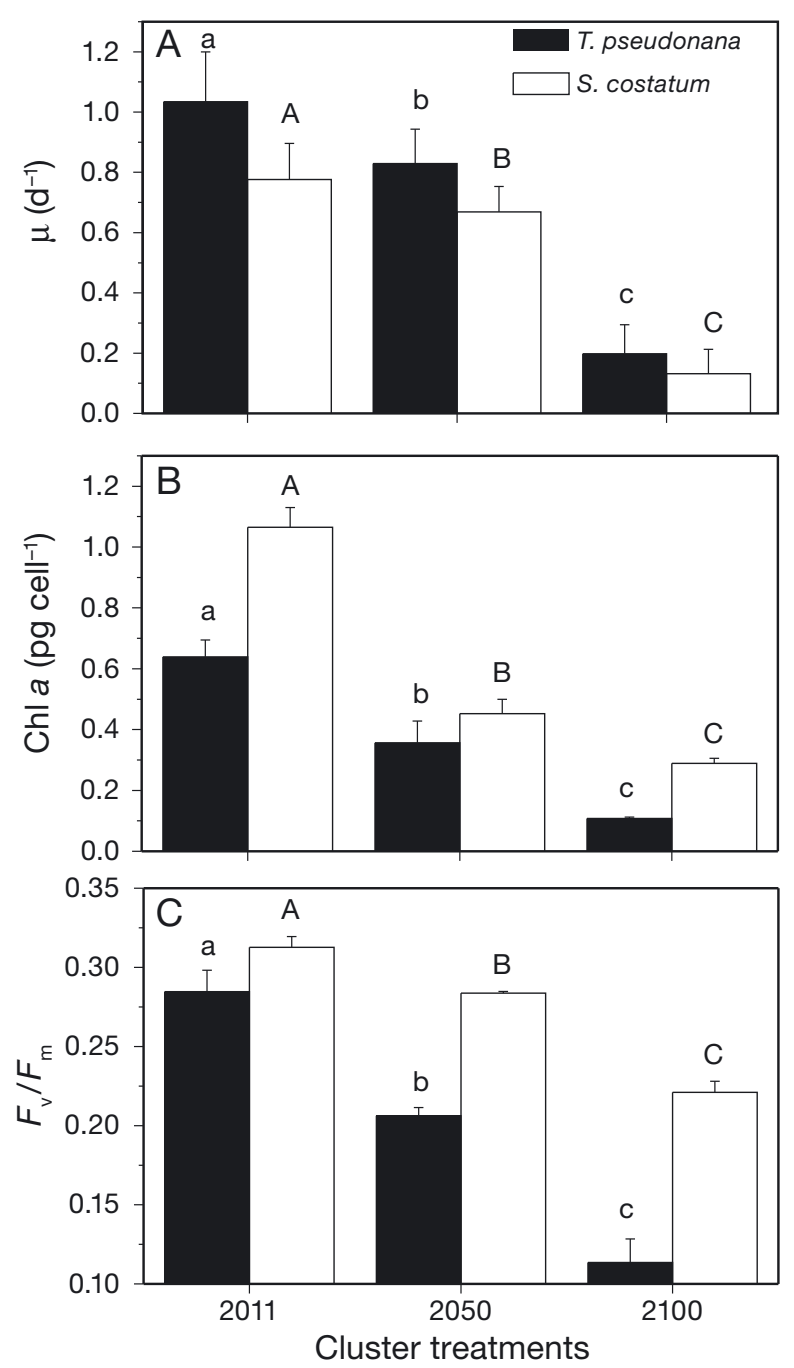

Fig. 2. (A) Growth rate $\mu$, (B) chl a content, and (C) quantum yield $F_{\mathrm{v}} / F_{\mathrm{m}}$ of Thalassiosira pseudonana and Skeletonema costatum under 3 cluster scenarios. Error bars represent SD (A: $\mathrm{n}=9$, and $\mathrm{B}, \mathrm{C}: \mathrm{n}=3$ ). Different letters indicate significant differences $(\mathrm{p}<0.05)$ among the different cluster conditions in T. pseudonana (lowercase letters) or $S$. costatum (uppercase letters), respectively

\section{RESULTS}

The specific growth rates of Thalassiosira pseudonana and Skeletonema costatum were significantly $(p=0.001)$ different among the 3 scenarios, with successive decreases from the 2011 scenario to the 2100 scenario (Fig. 2A). Compared to the 2011 scenario, the specific growth rates of $T$. pseudonana decreased by about 18 and $79 \%$, and those of $S$. costatum decreased by about 14 and $83 \%$, in the 2050 and 2100 scenarios, respectively (Fig. 2A). Compared to the 2011 scenario, chl a content decreased by about 
$44 \%$ under 2050 conditions, by $83 \%$ under the 2100 scenario in T. pseudonana, and by 58 and $73 \%$ in $S$. costatum correspondingly (Fig. 2B). Likewise, the $F_{\mathrm{v}} / F_{\mathrm{m}}$ values of both species decreased significantly in a stepwise manner from the 2011 scenario to the 2100 scenario ( $p=0.001$; Fig. $2 \mathrm{C}$ ), being reduced by $28 \%$ in the 2050 treatment and by $60 \%$ in the 2100 scenario for T. pseudonana and by 9 and $29 \%$ in $S$. costatum, respectively.

Cellular POC contents were higher in the 2050 and 2100 scenarios than in cells grown under the 2011 scenario conditions. On average, the cells of T. pseudonana contained 1.3 and 1.4 times more POC under the 2050 and 2100 scenarios, respectively, than the cells grown under the 2011 scenario. For S. costatum, POC cell quotas were 1.4 and 2.1 times higher under the 2050 and 2100 scenarios, respectively (Fig. 3A). However, there were no significant differences in $T$. pseudonana for the cellular PON content among the 3 different scenarios ( $\mathrm{p}=0.33$ ). The only difference observed was for $S$. costatum, in which PON content was increased by $47 \%$ in the 2100 scenario ( $p=$ 0.012 ; Fig. 3B). The ratio of POC:PON significantly increased in T. pseudonana from the 2011 scenario to the 2100 scenario ( $p=0.001$ ), being 29 and $47 \%$ higher under the 2050 and 2100 scenarios, respectively (Fig. 3C). For S. costatum, the POC:PON ratio was 40 and $43 \%$ higher under the 2050 and 2100 scenarios, respectively ( $\mathrm{p}=0.002)$.

There were only marginal differences in cellular BSi content for $T$. pseudonana among the scenarios ( $p=0.063$ ), with values of about $0.05 \mathrm{pmol} \mathrm{cell}^{-1}$. In contrast, cellular BSi of $S$. costatum increased significantly ( $p=0.001$ ), by 40 and $100 \%$ in the 2050 and 2100 scenarios, respectively (Fig. 4A). The highest cellular BSi content was found in the 2100 scenario, with a value of $0.21 \pm 0.02 \mathrm{pmol}^{\mathrm{c} e l l^{-1}}$. In T. pseudonana, due to invariant BSi content combined with increased POC content, the cellular ratio of BSi to POC (BSi:C) significantly decreased from the 2011 scenario to the 2100 scenario $(p=0.001)$. In contrast, for $S$. costatum, because both BSi and POC increased across the 3 scenarios, there was no significant difference in BSi:C ratios among the different scenarios $(\mathrm{p}=0.11$; Fig. 4B)

\section{DISCUSSION}

The growth rates of both diatom species decreased in the experimental setup that mimicked combined future higher $\mathrm{CO}_{2}$, increased light exposures and decreased nutrient availability. As more and more
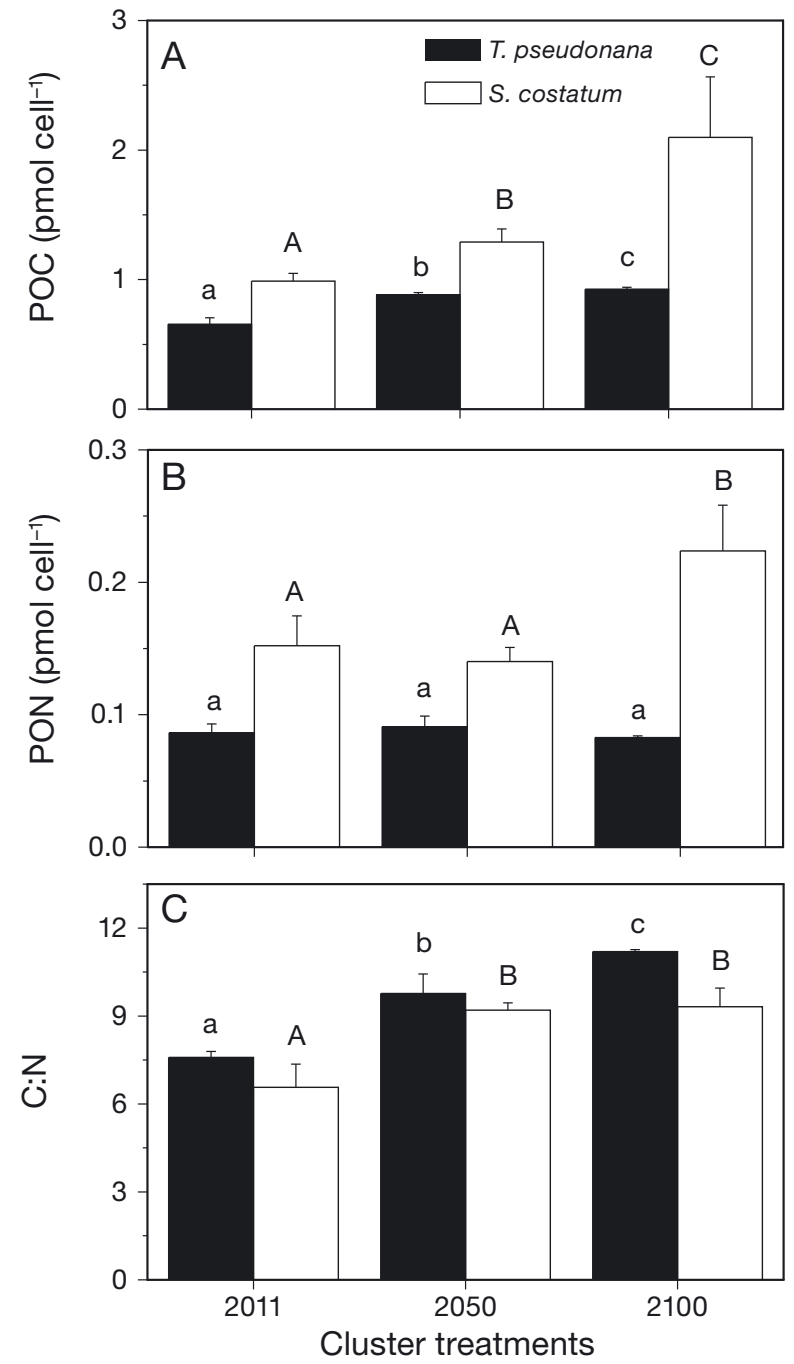

Fig. 3. Changes in cellular contents of (A) particulate organic carbon (POC) and (B) particulate organic nitrogen (PON), and (C) the ratio of POC to PON (C:N) of Thalassiosira pseudonana and Skeletonema costatum acclimated for $2 \mathrm{wk}$ under 3 cluster scenarios. Error bars represent SD $(n=3)$. Different letters indicate significant differences $(p<0.05)$ among the different cluster conditions in $T$. pseudonana (lowercase

letters) or $S$. costatum (uppercase letters), respectively

$\mathrm{CO}_{2}$ dissolves into the oceans, non-reversible OA and associated carbonate chemistry changes will definitely affect diatom physiology (reviewed in Gao $\&$ Campbell 2014). These effects have the potential to interact additively or synergistically with concurrent changes in nutrients, light and/or UV exposures (Gao et al. 2012a,b, Y. Li et al. 2012).

The same 2 Thalassiosira pseudonana and Skeletonema costatum isolates investigated in the present study showed enhanced growth rates under reduced levels $(<18 \%)$ of sunlight, but their growth rates were not affected at $30 \%$ incident solar PAR during nutri- 

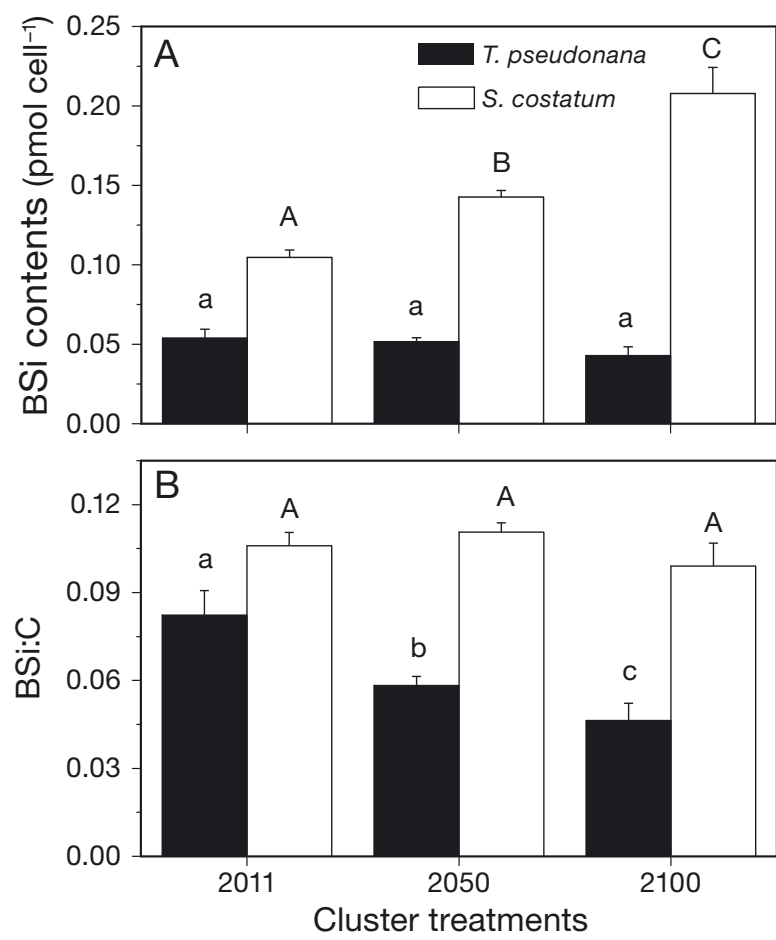

Fig. 4. (A) Biogenic silica (BSi) cellular contents, and (B) BSi to particulate organic carbon ratios (BSi:C) of Thalassiosira pseudonana and Skeletonema costatum acclimated for $2 \mathrm{wk}$ under 3 cluster scenarios. Error bars represent SD (n=3). Different letters indicate significant differences $(p<0.05)$ among the different cluster conditions in $T$. pseudonana (lowercase letters) or S. costatum (uppercase letters), respectively

ent-repleted growth (Gao et al. 2012b). However, their growth rates did not change with the combination of increased levels of $\mathrm{CO}_{2}$ and light (Gao et al. 2012b, their Fig. 2) as applied to the clusters in the present study. In contrast, with reduced availability of nutrients in the present work, increased light exposure to about $30 \%$ of incident sunlight significantly decreased their growth and photosynthetic performance (Fig. 2). While it is well known that limitation of light and nutrients can result in less growth (Saito et al. 2008), our data along with previous work (Gao et al. 2012b) clearly showed 30\% incident sunlight only inhibited growth under nutrient-limited conditions.

The cluster approach (Boyd et al. 2010, Xu et al. in press) reflects an empirical picture of future general changes that will happen in progressively stratified pelagic waters and is not intended to be taken as an exact model of any specific time or place. Since changes in seawater $\mathrm{pCO}_{2}$ and $\mathrm{pH}$ and stratificationrelated processes such as light exposure and nutrient supply will differ in different regimes and latitudes, effects of multiple ocean change factors examined in one area may not be applicable for other regions. Of course, this is true of the current ocean, as well as the future ocean, i.e. no experimental scenario can be considered to be universally applicable. Whatever conditions are chosen for any experiment, whether it is a single- or multiple-variable study must be considered as a model perturbation to ascertain the general trends resulting from changing environmental factor(s), and not as a precise prediction of exact levels of each factor.

Experimental protocols can often affect the outcomes of incubation studies. For instance, the same diatom species can exhibit different growth responses to OA between lab and mesocosm experiments (reviewed in Gao \& Campbell 2014). Consequently, the data obtained in the present study should be interpreted carefully to reflect the general responses of these 2 diatoms grown under the experimental conditions chosen. Obviously, future experiments may be needed that incorporate additional variables, particularly warming, to arrive at a more complete picture of likely future trends. For instance, $\mathrm{Xu}$ et al. (2014) take a cluster experimental approach to understanding how warming, acidification, irradiance changes and iron availability affect the growth of 2 Antarctic phytoplankton species.

With enhanced stratification expected with global warming, decreased availability of nutrients due to reduced upward transport will coincide with increased exposures of phytoplankton cells in the UML to solar radiation. Such ocean changes have been suggested to be leading to current decreases in marine primary productivity (Behrenfeld et al. 2006, Boyce et al. 2010, Steinacher et al. 2010). With replete nutrients, increased $\mathrm{pCO}_{2}$ availability and changed carbonate chemistry have been shown either to not affect the growth of diatoms (Riebesell et al. 1993, Chen \& Gao 2003, Yang \& Gao 2012) or to stimulate it (Schippers et al. 2004, Kim et al. 2006, Wu et al. 2010, Gao et al. 2012b). However, diatom responses could be opposite to these under conditions of light-stress (Gao et al. 2012b, Li \& Campbell 2013). In the diatom Phaeodactylum tricornutum, nitrogen limitation in combination with OA resulted in more pronounced effects on its growth compared with an OA treatment alone, and led to an increased ratio of POC:PON (W. Li et al. 2012).

The C:N ratio, an important indicator of potential N-limitation of phytoplankton growth (Donaghay et al. 1978), increased with the simulated future climate changes (Fig. 3). Limited supplies of phosphorus or nitrate are known to increase the ratio of POC to PON in S. costatum (Gervais \& Riebesell 2001) and P. tri- 
cornutum (W. Li et al. 2012). Increasing C:N ratios imply more carbon may be removed to the deep sea by the 'biological pump' relative to the amount of nitrogen consumed by phytoplankton, which has potential implications for the global carbon cycle as well as for increases in deep water hypoxia (Riebesell et al. 2007). Higher C:N ratios also reflect lower nutritional value of phytoplankton-produced organic matter (Ziska \& Bunce 2006), which may affect the efficiency of bacterial degradation and zooplankton reproduction, thus having further implications for marine biogeochemical processes (Riebesell et al. 2007).

$\mathrm{Si}$ availability is a key factor in regulation of diatom growth in open oceans, and this group dominates the biogeochemical cycling of Si. Diatom mineralization is sensitive to numerous factors, such as temperature, light, and nutrient and trace metal availability (Hutchins \& Bruland 1998, De La Rocha et al. 2000, Sarthou et al. 2005). Our results showed that the BSi content of $S$. costatum increased in the future scenarios, but BSi per cell did not change significantly in $T$. pseudonana. It is notable that these increasing or invariant cellular BSi quotas occurred despite sequentially decreasing concentrations of silicate in the medium (Fig. 1B); lower dissolved silicate (DSi) concentrations are usually thought to result in reduced levels of silicification (Paasche 1975, Brzezinski et al. 1990).

The differential responses in cellular BSi of the 2 diatoms to future ocean changes could be attributed to species-specific physiology. S. costatum is known to possess a periplasmic carbonic anhydrase (Nimer et al. 1998), which may favor silicification while catalyzing interconversion of $\mathrm{HCO}_{3}{ }^{-}$and $\mathrm{CO}_{2}$ at the cell's surface. For $S$. costatum, increased cellular BSi content with the simulated future ocean changes might have led to less photoinhibition, as reflected in the much smaller reduction of the maximal quantum yield compared with T. pseudonana. Higher BSi contents are consistent with a thicker siliceous frustule, which has been suggested to play a role in photoprotection (reviewed in Raven \& Waite 2004).

In the present study, the BSi to POC production ratio decreased in T. pseudonana in the future scenarios, due largely to increasing POC cell-1 (Fig. 3A) combined with relatively invariant BSi cell ${ }^{-1}$ (Fig. 4A). In contrast, the BSi:POC ratio was unchanged in $S$. costatum under the future scenarios, as both increased simultaneously. Previous work has suggested that BSi:POC ratios of other diatoms often decline with increasing $\mathrm{pCO}_{2}$, including the centric diatom T. weissflogii (Milligan et al. 2004), which is closely related to the $T$. pseudonana used in the present study and in 2 species of the pennate diatom Pseudonitzschia (Sun et al. 2011, Tatters et al. 2012). In our experiments, BSi:POC ratios also either decreased or stayed the same at higher $\mathrm{pCO}_{2}$. Other combinations of potential environmental change factors may yield different outcomes; for instance, an interactive effect of high light and iron reduced BSi:POC ratios in an incubated Ross Sea phytoplankton assemblage, but $\mathrm{pCO}_{2}$ had no effect (Feng et al. 2010). The results we obtained in the future scenarios imply that $\mathrm{Si}$ cell quotas and BSi:POC ratios may also respond in species-specific ways to future combinations of climate change factors.

Changing elemental stoichiometry is one of the few mechanisms by which biology can alter ocean carbon storage, and increased $\mathrm{C}: \mathrm{N}$ ratios with progressive ocean changes might increase the efficiency of the marine biological carbon pump. However, decreased primary productivity will certainly reduce the overall downward transport of carbon. In the present study, growth rates decreased while $\mathrm{C}: \mathrm{N}$ ratios increased under the projected future conditions. These antagonistic effects on the efficiency of organic carbon removal to the deep sea raise further uncertainties regarding our understanding of the potential ecological and biogeochemical impacts of future ocean changes.

Acknowledgements. This study was supported by the Chinese National Natural Science Foundation (No. 41430967, No. 41106093, No. 41120164007), Joint project of NSFC and Shandong province (Grant No. U1406403), Strategic Priority Research Program of CAS (Grant No. XDA11020302), Program for Changjiang Scholars and Innovative Research Team (IRT_13R51), SOA (GASI-03-01-02-04), China-Japan collaboration project from MOST (S2012GR0290), Natural Science Foundation of the Higher Education Institutions of Jiangsu Province (12KJB170002) and US National Science Foundation grants OCE 0962309 and 1260490 to D.A.H. Visits by D.A.H. to Xiamen were supported by the '111' (B07034) project of the Chinese Ministry of Education.

\section{LITERATURE CITED}

Behrenfeld MJ, O'Malley RT, Siegel DA, McClain CR and others (2006) Climate-driven trends in contemporary ocean productivity. Nature 444:752-755

> Boyce DG, Lewis MR, Worm B (2010) Global phytoplankton decline over the past century. Nature 466:591-596

Boyd PW (2011) Beyond ocean acidification. Nat Geosci 4: 273-274

> Boyd PW, Strzepek R, Fu F, Hutchins DA (2010) Environmental control of open-ocean phytoplankton groups: now and in the future. Limnol Oceanogr 55:1353-1376

> Brzezinski MA, Nelson DM (1995) The annual silica cycle in the Sargasso Sea near Bermuda. Deep-Sea Res I 42: 1215-1237 
Brzezinski M, Olson R, Chisholm S (1990) Silicon availability and cell-cycle progression in marine diatoms. Mar Ecol Prog Ser 67:83-96

Chen X, Gao K (2003) Effect of $\mathrm{CO}_{2}$ concentrations on the activity of photosynthetic $\mathrm{CO}_{2}$ fixation and extracelluar carbonic anhydrase in the marine diatom Skeletonema costatum. Chin Sci Bull 48:2616-2620

- De La Rocha CL, Hutchins DA, Brzezinski MA, Zhang Y (2000) Effects of iron and zinc deficiency on elemental composition and silica production by diatoms. Mar Ecol Prog Ser 195:71-79

> Donaghay PL, Demanche JM, Small LF (1978) On predicting phytoplankton growth rates from carbon: nitrogen ratios. Limnol Oceanogr 23:359-362

Falkowski PG, Barber RT, Smetacek V (1998) Biogeochemical controls and feedbacks on ocean primary production. Science 281:200-206

- Feng Y, Warner ME, Zhang Y, Sun J and others (2008) Interactive effects of increased $\mathrm{pCO}_{2}$, temperature and irradiance on the marine coccolithophore Emiliania huxleyi (Prymnesiophyceae). Eur J Phycol 43:87-98

- Feng Y, Hare CE, Leblanc K, Rose JM and others (2009) Effects of increased $\mathrm{pCO}_{2}$ and temperature on the North Atlantic spring bloom. I. The phytoplankton community and biogeochemical response. Mar Ecol Prog Ser 388: 13-25

Feng Y, Hare CE, Rose JM, Handy SM and others (2010) Interactive effects of iron, irradiance and $\mathrm{CO}_{2}$ on Ross Sea phytoplankton. Deep-Sea Res I 57:368-383

Fu FX, Warner ME, Zhang Y, Feng Y, Hutchins DA (2007) Effects of increased temperature and $\mathrm{CO}_{2}$ on photosynthesis, growth and elemental ratios of marine Synechococcus and Prochlorococcus (Cyanobacteria). J Phycol 43:485-496

Fu FX, Yu E, Garcia NS, Gale J, Luo Y, Webb EA, Hutchins DA (2014) Differing responses of marine $\mathrm{N}_{2}$ fixers to warming and consequences for future diazotroph community structure. Aquat Microb Ecol 72:33-46

Gao K, Campbell DA (2014) Photophysiological responses of marine diatoms to elevated $\mathrm{CO}_{2}$ and decreased $\mathrm{pH}$ : a review. Funct Plant Biol 41:449-459

Gao K, Ruan Z, Villafane VE, Gattuso JP, Helbling EW (2009) Ocean acidification exacerbates the effect of UV radiation on the calcifying phytoplankter Emiliania huxleyi. Limnol Oceanogr 54:1855-1862

> Gao K, Helbling EW, Häder DP, Hutchins DA (2012a) Responses of marine primary producers to interactions between ocean acidification, solar radiation, and warming. Mar Ecol Prog Ser 470:167-189

Gao K, Xu J, Gao G, Li Y and others (2012b) Rising $\mathrm{CO}_{2}$ and increased light exposure synergistically reduce marine primary productivity. Nat Clim Change 2:519-523

> Gervais F, Riebesell U (2001) Effect of phosphorus limitation on elemental composition and stable carbon isotope fractionation in a marine diatom growing under different $\mathrm{CO}_{2}$ concentrations. Limnol Oceanogr 46:497-504

Hare CE, Leblanc K, DiTullio GR, Kudela RM and others (2007) Consequences of increased temperature and $\mathrm{CO}_{2}$ for phytoplankton community structure in the Bering Sea. Mar Ecol Prog Ser 352:9-16

> Hennon GM, Quay P, Morales RL, Swanson LM, Armbrust EV (2014) Acclimation conditions modify physiological response of the diatom Thalassiosira pseudonana to elevated $\mathrm{CO}_{2}$ concentrations in a nitrate-limited chemostat. J Phycol 50:243-253
Hutchins DA, Bruland KW (1998) Iron-limited diatom growth and Si: $\mathrm{N}$ uptake ratios in a coastal upwelling regime. Nature 393:561-564

Hutchins DA, Mulholland MR, Fu F (2009) Nutrient cycles and marine microbes in a $\mathrm{CO}_{2}$-enriched ocean. Oceanography (Wash DC) 22:128-145

> Hutchins DA, Fu FX, Webb EA, Walworth N, Tagliabue A (2013) Taxon-specific response of marine nitrogen fixers to elevated carbon dioxide concentrations. Nat Geosci 6: 790-795

Kim JM, Lee K, Shin K, Kang JH and others (2006) The effect of seawater $\mathrm{CO}_{2}$ concentration on growth of a natural phytoplankton assemblage in a controlled mesocosm experiment. Limnol Oceanogr 51:1629-1636

Li G, Campbell DA (2013) Rising $\mathrm{CO}_{2}$ interacts with growth light and growth rate to alter photosystem II photoinactivation of the coastal diatom Thalassiosira pseudonana. PLoS ONE 8:e55562

Li W, Gao K, Beardall J (2012) Interactive effects of ocean acidification and nitrogen-limitation on the diatom Phaeodactylum tricornutum. PLoS ONE 7:e51590

Li Y, Gao K, Villafa e VE, Helbling EW (2012) Ocean acidification mediates photosynthetic response to UV radiation and temperature increase in the diatom Phaeodactylum tricornutum. Biogeosciences 9:3931-3942

Milligan AJ, Varela D, Brzezinski MA, Morel FMM (2004) Dynamics of silicon metabolism and silicon isotopic discrimination in a marine diatom as a function of $\mathrm{pCO}_{2}$. Limnol Oceanogr 49:322-329

Nimer NA, Warren M, Merrett MJ (1998) The regulation of photosynthetic rate and activation of extracellular carbonic anhydrase under $\mathrm{CO}_{2}$-limiting conditions in the marine diatom Skeletonema costatum. Plant Cell Environ 21:805-812

Paasche E (1975) Growth of the plankton diatom Thalassiosira nordenskioeldii Cleve at low silicate concentrations. J Exp Mar Biol Ecol 18:173-183

Raven JA, Waite AM (2004) The evolution of silicification in diatoms: inescapable sinking and sinking as escape? New Phytol 162:45-61

Riebesell U, Tortell PD (2011) Effects of ocean acidification on pelagic organisms and ecosystems. In: Gattuso JP, Hansson L (eds) Ocean acidification. Oxford University Press, Oxford, p 291-311

> Riebesell U, Wolf-Gladrow DA, Smetacek VS (1993) Carbon dioxide limitation of marine phytoplankton growth rates. Nature 361:249-251

> Riebesell U, Schulz KG, Bellerby RGJ, Botros M and others (2007) Enhanced biological carbon consumption in a high $\mathrm{CO}_{2}$ ocean. Nature 450:545-548

Saito MA, Goepfert TJ, Ritt JT (2008) Some thoughts on the concept of colimitation: three definitions and the importance of bioavailability. Limnol Oceanogr 53:276-290

Sarthou G, Timmermans KR, Blain S, Tréguer P (2005) Growth physiology and fate of diatoms in the ocean: a review. J Sea Res 53:25-42

Schippers P, Lürling M, Scheffer M (2004) Increase of atmospheric $\mathrm{CO}_{2}$ promotes phytoplankton productivity. Ecol Lett 7:446-451

- Shi D, Xu Y, Hopkinson BM, Morel FMM (2010) Effect of ocean acidification on iron availability to marine phytoplankton. Science 327:676-679

Steinacher M, Joos F, Frölicher TL, Bopp L and others (2010) Projected 21st century decrease in marine productivity: a multi-model analysis. Biogeosciences 7:979-1005 
Sun J, Hutchins DA, Feng Y, Seubert EL, Caron DA, Fu FX (2011) Effects of changing $p \mathrm{CO}_{2}$ and phosphate availability on domoic acid production and physiology of the marine harmful bloom diatom Pseudo-nitzschia multiseries. Limnol Oceanogr 56:829-840

Sunda WG, Price NM, Morel FMM (2005) Trace metal ion buffers and their use in culture studies. In: Andersen RA (ed) Algal culturing techniques. Elsevier Academic Press, London, p 35-63

Tatters AO, Fu FX, Hutchins DA (2012) High $\mathrm{CO}_{2}$ and silicate limitation synergistically increase the toxicity of a harmful bloom diatom. PLoS ONE 7:e32116

Tatters AO, Roleda MY, Schnetzer A, Fu F and others (2013) Short-and long-term conditioning of a temperate marine diatom community to acidification and warming. Philos Trans R Soc B 368:20120437

Tortell PD, Rau GH, Morel FMM (2000) Inorganic carbon acquisition in coastal Pacific phytoplankton communities. Limnol Oceanogr 45:1485-1500

> Tortell PD, Payne CD, Li YY, Trimborn S and others (2008) $\mathrm{CO}_{2}$ sensitivity of Southern Ocean phytoplankton. Geophys Res Lett 35:L04605, doi:10.1029/2007GL032583

Tseng CM, Wong GT, Lin II, Wu CR, Liu KK (2005) A unique seasonal pattern in phytoplankton biomass in lowlatitude waters in the South China Sea. Geophys Res Lett

Editorial responsibility: Katherine Richardson, Copenhagen, Denmark
32:L08608, doi:10.1029/2004GL022111

- Verity PG (1982) Effects of temperature, irradiance, and day length on the marine diatom Leptocylindrus danicus Cleve. III. Dark respiration. J Exp Mar Biol Ecol 60:197-207

$>$ Welschmeyer NA (1994) Fluorometric analysis of chlorophyll $\mathrm{a}$ in the presence of chlorophyll $\mathrm{b}$ and pheopigments. Limnol Oceanogr 39:1985-1992

> Wu Y, Gao K, Riebesell U (2010) $\mathrm{CO}_{2}$-induced seawater acidification affects physiological performance of the marine diatom Phaeodactylum tricornutum. Biogeosciences 7:2915-2923

> Xu J, Gao K (2012) Future $\mathrm{CO}_{2}$-induced ocean acidification mediates physiological performance of a green tide alga. Plant Physiol 160:1762-1769

Xu K, Fu F, Hutchins DA (2014) Comparative responses of two dominant Antarctic phytoplankton taxa to interactions between ocean acidification, warming, irradiance, and iron availability. Limnol Oceanogr 59:1919-1931

- Yang G, Gao K (2012) Physiological responses of the marine diatom Thalassiosira pseudonana to increased $\mathrm{pCO}_{2}$ and seawater acidity. Mar Environ Res 79:142-151

Ziska LH, Bunce JA (2006) Plant responses to rising atmospheric carbon dioxide. In: Morison JIL, Morecroft MDP (eds) Plant growth and climate change. Blackwell Publishing, Oxford, p 17-47

Submitted: February 28, 2014; Accepted: September 1, 2014 Proofs received from author(s): November 10, 2014 